\title{
Wiesława Sajdek
}

Uniwersytet Humanistyczno-Przyrodniczy im. Jana Długosza w Częstochowie ORCID: 0000-0003-2495-3570

\section{BADANIA ALEKSANDRA BIRKENMAJERA NAD FILOZOFIA WITELONA JAKO INSPIRACJA DO ZMIANY OCENY ŚREDNIOWIECZA W PROGRAMACH EDUKACJI}

\begin{abstract}
Aleksander Birkenmajer's Research on the Philosophy of Witelon as an Inspiration to Change the Assessment of the Middle Ages in Education Programs
\end{abstract}

Summary: Both Birkenmajer's method of work and his achievements, can serve as an example of a appropriate scientific approach to the Middle Ages. The picture of the period he presented radically differs from the stereotypes still prevailing in school educational programmes. Aleksander Birkenmajer (1890-1967) was an prominent Polish medievalist. Owing to his comprehensive education he gained rare competence to work on medieval manuscripts. In his texts, he repeatedly highlights the close relatedness between the history of philosophy and the history of mathematics and natural sciences. The close relation between philosophy and the then science, albeit its scope was much narrower than the purview of today's natural sciences, became the methodological directive for him. In his research on the philosophy of Witelon, Birkenmajer emphasized the point that he was a philosopher - naturalist, using light in solving metaphysical problems, like many others did in his times, e.g. Richard Bacon or Robert Grosseteste. Witelo's Perspective is virtually a mathematical-physical treatise with a metaphysical introduction. Birkenmajer managed, among others, to determine that Witelon was the author of the treatise De natura daemonum, the acquaintance of which can have a significant impact on the understanding of his philosophical views as a whole. The Polish medievalist also discerned in the treaty some symptoms of the so-called 'theory of double truth', whose influence the Silesian scholar might not be quite aware. Birkenmajer brought out and

${ }^{1}$ Dr hab. Wiesława Sajdek, prof. UJD - pracuje w Instytucie Filozofii Uniwersytetu Humanistyczno-Przyrodniczego im. Jana Długosza w Częstochowie; e-mail: wsajdek@gmail.com. 
convincingly described certain aspects of Witelon's philosophy, which significantly delimit the possibility to construe his ideas in the neo-Platonic paradigm.

Keywords: scientific method of a medievalist, relationship between philosophy and science in the Middle Ages, Witelo a scientist and philosopher

\section{Wstęp}

Kilkanaście lat temu przygotowałam w formie artykułu omówienie stanu wiedzy studentów pierwszego roku na temat myśli średniowiecznej ${ }^{2}$. Rzecz dotyczyła osób studiujących różne kierunki, jak np. socjologia, ekonomia i in., głównie jednak pedagogika. Podstawą omówienia były przeprowadzone w ciągu kilku lat egzaminy pisemne z tego zakresu (ponad tysiąc prac) i dzisiaj chciałabym tylko przytoczyć swój ówczesny wniosek, że egzamin ów ujawnił w całej rozciągłości krążące pośród studiującej młodzieży stereotypy na temat tej epoki, nabyte we wcześniejszych latach nauczania. Czas przeznaczony na wykład okazał się o wiele za krótki, aby można było je skutecznie zmienić u wszystkich słuchaczy. Wiele wskazuje na to, że stereotypy owe funkcjonują niestety także dzisiaj. A oto stereotyp najbardziej krzywdzący, a nawet absurdalny: otóż młodzież pozostawała w mocnym przeświadczeniu, że w Średniowieczu ${ }^{3}$ prawdy wiary, jako podstawa światopoglądu, były przyjmowane bezrefleksyjnie, na zasadzie ślepej ufności, z zaangażowaniem jedynie emocjonalnej strony człowieka. Jest to $\mathrm{z}$ pewnością bliższe tak bardzo popularnemu dzisiaj fideizmowi niż prawdzie o tamtej epoce. Na przeciwnym biegunie znalazły się i takie wypowiedzi na temat Średniowiecza, które można uznać za trafione, jak np. ta: „Wiara człowieka powinna być wiarą rozumnego człowieka”. Inny popularny stereotyp poszerza tylko zakresowo wcześniejszy, wiążąc się z wyobrażeniem, że myślenie w tej epoce było nienaukowe i w ogóle nielogiczne oraz prymitywne. Temu zadaje kłam nawet pobieżna znajomość czasów tworzących się wówczas uniwersytetów:

Związek logicznego myślenia z wiarą wydaje się najcenniejszym dziedzictwem kulturowym średniowiecza. Tego rodzaju harmonii szukano wśród niezliczonych „spotkań dyskusyjnych", obowiązkowych i spontanicznych, uniwersyteckich i pozauniwersyteckich, prowadzonych często w bardzo gorącej atmosferze ${ }^{4}$.

2 Wiesława Sajdek, „Recepcja historii filozofii średniowiecznej wśród studentów”, Społeczeństwo i Rodzina. Stalowowolskie Studia KUL 1 (2004), 13-22.

${ }_{3}^{3}$ Duża litera wskazuje na formację kulturową, jak w przypadku innych nazw tego rodzaju - np. „Renesans” czy też „Oświecenie”, a nie na historyczne, ogólne ramy czasowe, jak np. starożytność, średniowiecze, nowożytność i współczesność.

${ }^{4}$ Por. teksty na ten temat kilkunastu autorów, związanych na ogół ze środowiskiem Katolickiego Uniwersytetu Lubelskiego, w redagowanej przeze mnie monografii pt. Czasy katedr - czasy 
Epoka Średniowiecza nie cieszyła się i nadal nie cieszy odpowiednim zainteresowaniem osób mających wpływ na programy szkolne na różnych poziomach nauczania. Istnieje wiele przyczyn, dla których należałoby to zmienić. Jedną z nich, najważniejszą, jest bez wątpienia prawda historyczna o ówczesnych uniwersytetach, sposoby prowadzenia dyskusji w „złotym wieku scholastyki” oraz wskazówki, które można czerpać stąd i dzisiaj z wielkim pożytkiem dla wychowania integralnego człowieka o niesprzecznym logicznie światopoglądzie. Programy nauczania dotyczące Średniowiecza bywają od niej niekiedy bardzo oddalone. Począwszy od absurdalnych przekłamań historycznych, przedstawiających tę epokę jako czas „Zabobonów oraz ciemnoty”, aż po wielokroć powielany „pewnik”, że początek bujnego rozwoju nauki w Europie należy łączyć z protestantyzmem. Nie umniejszając w niczym prawdziwej roli osób związanych z protestantyzmem, mających wpływ na postęp naukowy, należy jednak we właściwy sposób przedstawić także wcześniejsze stulecia. Tym bardziej, że nie stanowią one epoki jednolitej pod względem kulturowym, a granice czasowe Średniowiecza bywają także różnie rozumiane.

Nader często za początek filozofii średniowiecznej, która wówczas, podobnie jak w starożytności, obejmowała wszelkie ludzkie rzetelne poznanie, uważa się dopiero wiek IX, podkreślając zwłaszcza te procesy, sprzyjające rozwojowi zainteresowań poznawczych, które znajdują zwieńczenie w szkole pałacowej Karola Wielkiego. Niekiedy jednak jako filozoficzny początek Średniowiecza przyjmuje się już IV wiek po narodzeniu Chrystusa, wskazując na ogromną rolę św. Augustyna i jego dzieł, zwłaszcza we wczesnym Średniowieczu, czyli aż do wieku XII włącznie. Jeśli o Boecjuszu (480-525) zwykło się mówić jako o „ostatnim Rzymianinie”, to tym bardziej starożytną kulturę filozoficzną reprezentuje św. Augustyn, biskup Hippony, żyjący w latach 354-430. Urodzony w Tagaście, w rzymskiej prowincji Numidii, swoją intelektualną formację zawdzięcza środowisku rzymskiemu oraz rzymskiej kulturze, rozwijającej się w przemożnym świetle myśli greckiej. We Wprowadzeniu Agnieszki Kijewskiej do wydanego kilka lat temu Przewodnika do filozofii średniowiecznej. Od św. Augustyna do Joachima z Fiore możemy przeczytać, że:

[...] omawiany w tym tomie okres stanowi pewną dającą się wyodrębnić całość. Rozpoczyna się omówieniem myśli św. Augustyna, który jest wprawdzie reprezentantem filozofii starożytności chrześcijańskiej, niemniej jego wpływ na myśl wieków średnich był ogromny i z tego względu nie można było go pominąć. Z kolei dokonania Boecjusza, zaprezentowane $\mathrm{w}$ kolejnym rozdziale, stanowily swoisty pomost pomiędzy myślą starożytną a średniowieczną, choć niewątpliwie nie należy traktować Boecjusza jedynie jako przekaziciela dokonań starożytnych średniowieczu. Chronologicznie jednak Boecjusz stoi na granicy tych dwóch epok ${ }^{5}$.

uniwersytetów. Źródła jedności narodów Europy (Lublin: Wydawnictwo KUL 2005). Przytoczony fragment pochodzi ze wstępu Od redakcji - tamże, 6 .

${ }_{5}$ Agnieszka Kijewska, „Wprowadzenie”, w: Przewodnik po filozofii średniowiecznej. Od św. Augustyna do Joachima z Fiore, red. Agnieszka Kijewska (Kraków: Wydawnictwo WAM 2012), 9. 
Jedną z bardziej zakłamanych informacji na temat kultury Średniowiecza jest rzekoma "przepaść" pomiędzy formacją intelektualną, jaką otrzymywały osoby żyjące w starożytności, a tą, którą można było uzyskać w omawianej epoce. Program nauczania na średniowiecznych uniwersytetach oraz obszar zainteresowań ówczesnych uczonych stawał się do pewnego okresu coraz bardziej urozmaicony i bogaty, aż do wieku XIII, ale związane to było wszak z odzyskiwaniem starożytnego dziedzictwa. Więź pomiędzy kulturą umysłową Starożytności i rodzącego się Średniowiecza pozwala tylko umownie przyjmować granicę pomiędzy tymi epokami: „Oczywiście wszelkie proponowane datowania mają charakter umowny, wskazują jedynie na pewne wydarzenia, które miały wpływ na intelektualny kształt danej epoki, a nie na moment rzeczywistego "przejścia" pomiędzy poszczególnymi okresami"”.

Zdzisław Kuksewicz wskazuje na początki filozofii średniowiecznej w Europie łacińskiej w czasach biskupa rzymskiego Grzegorza Wielkiego: „Nie filozof to co prawda i nie całkiem „barbarzyńca”, bo wykształcony przedstawiciel spadkobierców arystokracji rzymskiej, ale równocześnie człowiek, który świetnie rozumiał nowe czasy, dając pełny program intelektualny początków nowej ery”’. Jest to z pewnością odpowiednie uzasadnienie przyjęcia określonej chronologii, które tutaj warto przytoczyć w obszerniejszym cytacie:

W ten sposób rozpoczynamy dzieje filozofii średniowiecznej od Grzegorza Wielkiego, a więc przełomu VI i VII wieku, a z Izydorem z Sewilli otwiera się okres ciągłej twórczości filozoficznej pierwszego okresu filozofii średniowiecznej, którego apogeum stanowi epoka karolińska, a schyłek - pokolenie postkarolińskie wieku X.

Po latach upadku kultury w wieku X, upadku towarzyszącego regresowi gospodarczo-społecznemu tych rejonów Europy, w których rozwijała się już filozofia, rozpoczyna się na gruncie nowej epoki rozwoju gospodarczego, społecznego i kulturowego w wieku XI następny okres filozofii średniowiecznej [...], w którym wiek XI wraz z determinującym ten okres rozwojem dialektyki i logiki stanowi przygotowanie renesansu wieku XII.

Aczkolwiek z punktu widzenia historii politycznej, gospodarczej i społecznej wiek XIII stanowi dalszy ciąg rozwoju, rozpoczętego w wieku XI, to dla filozofii prezentuje on inną jakość, którą uzyskuje w wyniku udostępnienia nowych, bogatszych źródeł w warunkach uzyskanej sprawności intelektualnej umożliwiającej ich twórcze przetworzenie. Te nowe źródła, nową wiedzę przyniósł kontakt z wyżej wtedy rozwiniętą kulturą arabsko-muzułmańską. Wiek XIII zatem to następny okres, „złoty wiek scholastyki”, szczytowy okres rozwoju, okres wielkich systemów filozoficznych, rozwoju uniwersyteckiej organizacji życia intelektualnego ${ }^{8}$.

6 Tamże.

7 Zdzisław Kuksewicz, Zarys filozofii średniowiecznej (Warszawa: Państwowe Wydawnictwo Naukowe 1973), 10.

8 Tamże, 10-11. 
Epoka Średniowiecza nie kończy się oczywiście na wieku XIII, aczkolwiek to stulecie było okresem jej największego rozkwitu. Przedmiot naukowego zainteresowania Aleksandra Birkenmajera, o którym tutaj będzie mowa, a więc życie i dorobek naukowy Witelona, śląskiego uczonego i filozofa, zamyka się właśnie w wieku XIII. Witelo wtedy bowiem żył i działał. Niektóre aspekty jego dorobku są symptomatyczne dla całej epoki i mogą stać się ilustracją tego, w jakim kierunku powinno postąpić ubogacenie i rozwinięcie pewnych wątków nauczania, często dotychczas przekłamanych.

\section{I}

Aleksander Birkenmajer (1890-1967) był bez wątpienia jednym z najwybitniejszych polskich uczonych badających dorobek myślicieli Średniowiecza w ubiegłym stuleciu. Jego rodzicami byli Ludwik Birkenmajer, matematyk i fizyk, związany wieloletnią pracą w średniej szkole rolniczej z Czernichowem, późniejszy profesor Uniwersytetu Jagiellońskiego, znakomity badacz i znawca życia oraz dzieła Mikołaja Kopernika, oraz Zofia Karlińska, córka dyrektora obserwatorium astronomicznego w Krakowie. Pradziadek Aleksandra, Antoni, pochodził spod Fryburga Bryzgowijskiego, ale jego dziadek, Józef Herman, był „zupełnie już spolszczony”, jak zauważył autor biogramu Ludwika Birkenmajera, najmłodszego spośród trojga dzieci Józefa Hermana9.

Czy Aleksandra Birkenmajera można uznać za samodzielnego filozofa, skoro jego życie upłynęło przede wszystkim na skrupulatnym badaniu dorobku innych myślicieli? Przyjmijmy jako pewnik, że nie można badać treści filozoficznych w konkretnych dokumentach bez uprzednich studiów dających możliwość dogłębnego ich zrozumienia. Czy można jednak je rozumieć bez osobistej refleksji, a więc bez samodzielnego filozofowania? Ta autentyczna samodzielność, a więc własny wysiłek intelektualny wkładany w filozofowanie, oznacza o wiele więcej niż spektakularne (zwykle pozorne) "nowości” w dziedzinie filozofii. Sokrates nade wszystko cenił sobie samodzielne „rodzenie” myśli. Bez porównania wyżej niż wszelkie popisy retoryczne sofistów, nawet tych najwybitniejszych, jak np. Protagoras, którego dorobek do dzisiaj pobudza do myślenia. Z drugiej strony jednak nie może być mowy o filozofowaniu bez kontaktu z żywym źródłem antycznym, bez naśladowania postawy Sokratesa.

Nie można być historykiem filozofii z prawdziwego zdarzenia bez uprawiania filozofii, która wszak domaga się kwestionowania wyników własnych przemyśleń. Nie sposób myśleć o filozofii bez dialogu, nawet jeśli miałby to być jedynie „dialog

9 Polski słownik biograficzny, t. II (Kraków: Nakładem Polskiej Akademii Umiejętności 1936), 102-104. 
duszy samej ze sobą"10, a w perspektywie platońskiej jest to najbardziej wzniosły rodzaj „dialogowania”. Birkenmajer jest uczonym o najwyższych kwalifikacjach, nie tylko dotyczących jego kompetencji, lecz także zdolności bezwzględnego tropienia prawdy w gąszczu średniowiecznych rękopisów, z pasją dziennikarza śledczego. Jeśli pojawi się cień wątpliwości, natychmiast skupia się na tropieniu niejasności, począwszy od rękopiśmiennych treści. Przy okazji niejasności, związanych z tłumaczeniem słowa forma w pismach Witelona, Birkenmajer podzielił się następującą refleksją: „[...] dla celu mojego wystarczy, jeżeli przy pomocy wyraźnej i bijącej w oczy paraleli zdołam osiągnąć jasną i niedwuznaczną interpretację samego tekstu, który (jak się okaże) i tutaj także nie został przez nikogo dotąd zrozumiany"11.

$\mathrm{Ta}$ - wydawałoby się - prosta dyrektywa metodologiczna badacza średniowiecznych tekstów nie jest dzisiaj właściwie ceniona, podobnie jak i jasna interpretacja treści, rzetelne podejście do tekstu, trzymanie się litery, zanim dojdzie do wydobywania zeń głębokich sensów oraz poszukiwania przy tym za wszelką cenę oryginalności. Rzetelność badawcza wymaga niekiedy mało efektownego tropienia szczegółów. Druga strona tej pozornie minimalistycznej postawy badawczej prowadzi do ustaleń, które następnie trudno będzie obalić, ponieważ oparte są na mocnym związku, a w istocie koniecznym sojuszu pomiędzy filozofią i filologią, uzupełnioną przez paleografię oraz niezbędną znajomość historycznych realiów epoki. Aleksander Birkenmajer we wspomnieniach swojego doktoranta, ks. prof. Mariana Kurdziałka, zaprzeczał, jakoby był historykiem filozofii średniowiecznej oraz historykiem filozofii w ogóle, zgadzając się co najwyżej, że jest historykiem nauk ścisłych, jako absolwent matematyki i filozofii, lub też historykiem literatury filozoficznej. Kiedy to mówił, z pewnością był już sławnym i uznanym mediewistą ${ }^{12}$. Jego zainteresowanie filozofią rozwinęło się oraz pogłębiło podczas studiów nad Witelonem, a więc od 1908 roku, kiedy zaczął badać dorobek współczesnych Witelonowi matematyków i astronomów. Przy tej okazji stało się jasne, że oni wszyscy - Campanus z Nawarry, Henryk Bate z Mechelenu oraz Witelo - znali i przyjaźnili się z Wilhelmem z Moerbeke, bliskim współpracownikiem i współbratem św. Tomasza z Akwinu, wybitnym tłumaczem dzieł Platona, Arystotelesa i Proklosa z greki na łacinę. Tak więc Birkenmajer nie tylko zaczął studiować myśl św. Tomasza, doszedłszy doń poprzez przekłady Wilhelma z Moerbeke, lecz także całą filozofię średniowieczną. Dzięki temu mógł spełnić naprawdę ogromne, wręcz wygórowane oczekiwania, jakie stawiał mediewistom Konstanty Michalski. Według niego bowiem:

${ }_{10}$ Por. Platona Teajtet (Warszawa: PWN 1959), 108: „[Sokrates] [...] a myśleniem nazywasz to samo, co i ja? [Teajtet] A ty co tak nazywasz? [Sokrates] Rozmowę, którą dusza sama z sobą prowadzi, cokolwiek weźmie pod uwagę. [...] tak mi się przedstawia dusza, kiedy rozmyśla - że niby rozmawia - sama sobie zadaje pytania i odpowiedzi daje i mówi «tak» i mówi «nie»".

${ }^{11}$ Birkenmajer, Aleksander, Biblioteka Jagiellońska, Przybytki 181/75 (dalej: BJ, Przyb.).

12 Marian Kurdziałek, „Aleksander Birkenmajer. «Historyk filozofii średniowiecznej»”, w: Średniowiecze $\mathrm{w}$ poszukiwaniu równowagi między arystotelizmem a platonizmem. Studia i artykuły (Lublin: TN KUL 1996), 8. 
[...] nie można tej wstępnej pracy nad rękopisem powierzyć filologowi. Przystępując do badań, historyk filozofii średniowiecznej sam, jako osoba kompetentna, musi prawidłowo odczytać rękopis i opisać go, przeprowadzić odpowiedzialną krytykę, interpretację i selekcję materiału, nie usuwając przy tym na drugi plan zagadnień filozoficznych. Aby tego wszystkiego dokonać i obiektywnie, ze zrozumieniem sformułować uogólnienie - historyk filozofii powinien być filozofem ${ }^{13}$.

Czy można tłumaczyć na inny język, np. z łaciny na polski, filozoficzne treści, jeśli się nie jest filozofem? Z pewnością nie można. Odpowiedź na to pytanie narzuca się z bezwzględną oczywistością przy okazji współczesnych prób tłumaczenia filozoficznych treści przez odpowiednie programy translatorskie. Oprócz stwierdzenia, że te programy z pewnością nie są doskonałe, budzi się poważna wątpliwość, czy kiedykolwiek będą choćby tolerowalne wobec specyfiki przedmiotu, którego dotyczą. Myśli o charakterze filozoficznym są zwykle bardzo mocno osadzone w głębokiej strukturze języka, dotykając tego, co najbardziej w człowieku źródłowe i intuicyjne. Nie sposób ich także zrozumieć bez znajomości szeroko pojętej kultury umysłowej, wyrażonej w piśmiennictwie, które powstało na podstawie tego właśnie języka. Doświadczenie żywych dialogów ma przy tym charakter komplementarny i jest równie konieczne. I jeszcze jedno pytanie, w gruncie rzeczy retoryczne: czy można poznać polską kulturę, zupełnie nie znając łaciny? Źródłowość języka dotyczy przecież nie tylko bogactwa żywej mowy tu i teraz, hic et nunc, lecz także przynajmniej tej epoki, kiedy ten język się tworzył jako język literatury oraz filozofii. W Polsce taką epoką był z pewnością Renesans, wcześniej pisano oraz filozofowano po łacinie, ale to właśnie łacińskie piśmiennictwo stało się bezpośrednim źródłem oraz inspiracją dla polskiej literatury. Dodajmy - nie tylko polskiej, lecz także, paralelnie, dla innych literatur europejskich, które współtworzą europejską kulturę umysłową, wypracowaną pomimo wojen oraz nadużywania przemocy. Ta kultura, mimo licznych niedoskonałości, naznaczona schyłkowością po apokaliptycznych wydarzeniach, które miały miejsce w ubiegłym stuleciu, może stać się i dzisiaj właściwym oparciem oraz uzasadnieniem dla jedności narodów Europy.

\section{II}

W wieku XIII, a więc w „złotym wieku scholastyki”, żył i tworzył filozoficzne rękopisy śląski filozof i uczony Witelon (lub Witeliusz), który urodził się ok. 1230 roku w okolicy Wrocławia i Lignicy. Birkenmajer zauważył, że Śląsk Witelo

13 A. Przymusiała, „Ks. Konstanty Michalski (1879-1947)”, Studia Philosophiae Christianae 1 (1966), 271. Za: Kurdziałek, „Aleksander Birkenmajer. «Historyk filozofii średniowiecznej»”, przyp. 10, 10-11. 
nazywał zawsze Polską ${ }^{14}$. Wypada teraz przypomnieć jeszcze inne, ważne informacje na jego temat. Najpierw studiował na Uniwersytecie Paryskim, gdzie miał uzyskać tytuł magistra artium. Zapoznał się tam z filozofią Arystotelesa i Platona, a także Awicenny i Awerroesa. Oprócz filozofii przyrody studiował także matematykę oraz czytał dzieła lekarskie. Następnie studiował w Padwie. Alistair C. Crombie pisze: „W średniowieczu istniały różne szkoły myślenia oparte na arystotelesowskiej koncepcji wszechświata"15 , po czym następuje dookreślenie pięciu takich szkół. Crombie wymienia więc dwie szkoły myślenia franciszkanów z Oksfordu, bardziej lub mniej ortodoksyjnych augustynistów, a pośród nich Roberta Bacona, który „[...] interesował się przede wszystkim bardzo żywo matematyczną, fizyczną, astronomiczną i medyczną stroną nauki Arystotelesa i Arabów, mniej natomiast zajmował się ich poglądami metafizycznymi” ${ }^{\prime 16}$.

Inną szkołę reprezentowali paryscy dominikanie, Albert Wielki i Tomasz z Akwinu, a jeszcze inaczej filozofowali zdecydowani awerroiści, jak Siger z Brabantu. Piątą szkołę średniowiecznego myślenia tworzyła „[...] grupa uczonych na uniwersytetach włoskich w Salerno, Padwie i Bolonii, gdzie do kwestii teologicznych przywiązywano mniejszą wagę niż w Anglii czy we Francji i gdzie studiowano Arystotelesa i Arabów głównie dla ich medycyny" ${ }^{17}$. W tej to atmosferze naukowej odbywał Witelo swoje padewskie studia. Towarzyszyły im obserwacje dotyczące zjawisk świetlnych. Na przykład w X księdze Perspektywy Witelo poświadcza, że widział tam cztery tęcze naraz, a działo się to o zachodzie słońca: et talem iridem non unam, nec duas tantum, sed et iam quatuor simul vidimus Paduae, sole iam ad vesperam declinate. W Padwie Witelo studiował traktat optyczny Alhazena, najwybitniejszego uczonego arabskiego w tej dziedzinie. Tam również nawiązał współpracę i zaprzyjaźnił się z Wilhelmem z Moerbeke, dominikaninem, wspomnianym już tutaj współpracownikiem św. Tomasza z Akwinu, wybitnym tłumaczem dzieł Arystotelesa z greki na łacinę, który także interesował się matematyką. To właśnie Witelon miał namówić Wilhelma z Moerbeke do tłumaczenia traktatów z zakresu matematyki oraz optyki. Poniżej zostaną przedstawione wyniki badań nad Witelonem, prowadzonych przed wojną przez młodego wówczas, ale już wtedy doskonale przygotowanego do swojej pracy Aleksandra Birkenmajera. Mogą one posłużyć jako znacząca ilustracja tego, jak wyglądało naprawdę życie uniwersyteckie oraz naukowe w interesującej nas epoce.

Historia myśli europejskiej wyłoniła pewne dzieła uznane za „kanoniczne” dla określonych myślicieli, jako najlepiej wyrażające ich filozofię ${ }^{18}$. Pozostała „reszta”

${ }^{14}$ Por. maszynopis odczytu radiowego (bez zaznaczonej daty), BJ, Przyb. 184/75.

${ }_{15}$ Alistair Cameron Crombie, Nauka średniowieczna i początki nauki nowożytnej, t. I (Warszawa: Instytut Wydawniczy PAX 1960), 84.

16 Tamże.

17 Tamże, 84-85.

${ }^{18}$ Por. Maciej Woźniczka, Marek Perek, „Wstęp. Relacja kanon - apokryf”, w: Apokryficzność (w) filozofii. Nie/anty/pozaortodoksyjne dyskursy filozoficzne, red. Maciej Woźniczka, Marek Perek 
miałaby więc stanowić co najwyżej mało istotne przyczynki. Tymczasem badanie tychże "przyczynków” może się okazać bardzo ważne dla lepszego zrozumienia istotnych rysów czyichś poglądów. Jest to uzasadnione zwłaszcza wobec myślicieli średniowiecznych, ciągle jeszcze zbyt mało zbadanych i znanych. Współczesna polska mediewistka, badająca średniowieczne rękopisy zgromadzone w Bibliotece Jagiellońskiej, zauważyła (na marginesie badań recepcji szkotyzmu w piętnastowiecznej Polsce):

Należy sobie uświadomić, że duża część średniowiecznych i nowożytnych kodeksów, nie tylko zresztą w Bibliotece Jagiellońskiej, nie jest jeszcze szczegółowo przebadana. Mimo iż nie należy się już spodziewać odkrycia odpisów dużych dzieł znanych autorów, bo te najłatwiej zauważyć i w większości zostały już skatalogowane, nie można jednak wykluczyć istnienia niewielkich, lecz ważnych tekstów, które mogą być jeszcze w przyszłości zidentyfikowane ${ }^{19}$.

Nieomal sto lat wcześniej, na początku lat 20. zeszłego stulecia, Aleksander Birkenmajer opublikował wyniki swoich prac źródłowych, prowadzonych na podstawie badań wybranych rękopisów średniowiecznych, w których wykazał istnienie nieznanego dotychczas traktatu Witelona pt. De natura daemonum ${ }^{20}$. Birkenmajer zauważył przy okazji, że szczegółowa analiza tego pisma mogłaby doprowadzić do „[...] oparcia o nową podstawę znajomości filozoficznego systemu śląskiego uczonego - co znów ze swej strony wymagałoby przeprowadzenia licznych parallel z Perspektywa, jako też z fałszywie Witelonowi przypisywanym pisemkiem De intelligentis [...]"21. O tym ostatnim pisemku pisze Etienne Gilson: „Początkowo pracę tę [tj. Memoriale rerum difficilium] przypisywano polskiemu filozofowi i uczonemu, Witelonowi, nadając jej tytuł O inteligencjach (De intelligentis), ale skoro cytowali ją autorzy żyjący przed Witelonem, obecnie pogląd ten już zarzucono"22.

(Częstochowa: Wydawnictwo im. S. Podobińskiego 2017), 14-15: „Zauważmy, że porządkowa interpretacja przeciwieństwa kanon - apokryf z piśmiennictwa religijnego odpowiada strukturalnie opozycji «filozoficzny - niefilozoficzny» i «naukowy - nienaukowy» w problemie demarkacji, w którym broni się przedmiotowej istotności i czystości kanonicznego rdzenia danej wspólnoty badawczej przed apokryficznymi kontaminacjami”.

${ }^{19}$ Lucyna Nowak, „Rękopiśmienne świadectwa recepcji pism Dunsa Szkota na Uniwersytecie Krakowskim. Katalog dzieł", w: Błogosławiony Jan Duns Szkot. 1308-2008. Materiały Międzynarodowego Sympozjum Jubileuszowego z okazji 700-lecia śmierci bt. Jana Dunsa Szkota, Katolicki Uniwersytet Lubelski Jana Pawła II, 8-10 kwietnia 2008, red. Edward I. Zieliński OFMConv, Roman Majeran (Lublin: Wydawnictwo KUL 2010), 744.

${ }^{20}$ Aleksander Birkenmajer, „Studia nad Witelonem”, cz. 1. „Dwa nieznane pisemka Witelona”, w: BJ, Przyb. 180/75. Na rewersie strony tytułowej: „Osobne odbicie z II tomu Archiwum dla badania historii filozofii w Polsce” (Kraków: Nakładem Polskiej Akademii Umiejętności 1921).

${ }^{21}$ Tamże, 10.

22 Etienne Gilson, Historia filozofii chrześcijańskiej w wiekach średnich (Warszawa: Instytut Wydawniczy PAX 1987), 236. W 1891 roku Witold Rubczyński ogłosił rozprawę, w której dowodził, że zaginiony traktat Witelona pt. De ordine entium jest tożsamy z De intelligentis. Podobnie sądził 
Polski uczony nabrał podejrzeń co do istnienia traktatu De natura daemonum dziesięć lat wcześniej, zanim ostatecznie opublikował wyniki swoich szczegółowych kwerend, podczas analiz treści Questiones Meteororum Mikołaja z Ores$\mathrm{me}^{23}$. Slady wpływów nowo odkrytego traktatu Witelona sięgają poza połowę XVI wieku, były więc to wpływy długotrwałe i rozległe.

Wszystkie cztery części Studiów nad Witelonem Aleksandra Birkenmajera były referowane podczas posiedzeń Polskiej Akademii Umiejętności w latach 1918-1922. Najpierw opublikował on nieznany wcześniej traktat Witelona pt. De natura daemonum, który znał ze skrótu zamieszczonego w rękopisie paryskim, pochodzącym z początku XV wieku, a następnie pełny tekst tego traktatu, pochodzący z początków XIV wieku, który odkrył w British Museum w Londynie w 1923 roku. Ten pełny tekst stanowi źródło nowych informacji o życiu Witelona oraz o jego dziele, np. pozwala na właściwszą niż dotychczas interpretację filozoficznej przedmowy Witelona do jego Perspektywy. Birkenmajer podkreśla, że przeciwstawienie wiedzy i wiary jest $\mathrm{w}$ nim słabsze niż $\mathrm{w}$ paryskim skrócie. $\mathrm{Z}$ rękopisu brytyjskiego wynika, że Witelo, który odbył studia kanonistyczne w Padwie, należał do kleru świeckiego - sam siebie określa bowiem jako Witelo plebanus. Traktat Witelona jest formalnie listem skierowanym do przyjaciela, a z przedmowy i zakończenia tego listu można wnosić, że przyjaciel ów protegował go u jednego z synów Henryka Pobożnego, najprawdopodobniej chodziło tutaj o Bolka Legnickiego. Ów list obejmuje dwie kwestie, bo oprócz rozważań o "naturze demonów” również „de causa primaria penitentiae in hominibus", a więc o pierwotnej przyczynie ludzkiej skruchy i żalu za grzechy. Nadto wiadomo, na podstawie tego rękopisu, że Witelo planował studia teologiczne w Padwie i z pewnością nie tylko tam studiował, lecz także i nauczał. Birkenmajer ustalił pochodzenie traktatu na lata 1266-1268, przypuszczając, że został on napisany najprawdopodobniej podczas ferii wielkanocnych w roku $1268^{24}$. Od początku roku 1269 Witelo przebywał w Viterbo, gdzie znajdowały się znane jeszcze Rzymianom źródła siarczane o leczniczych właściwościach, równie sławne jak

Clemens Baeumker [por. „Witelo, ein Philosoph und Naturforscher des XIII Jahrhunderts”, w: Beitraege zur Geschichte der Philosophie des Mittelalters, III: 2 (Münster 1908)]. Według Birkenmajera De intelligentis nie jest autorstwa Witelona i powstało ok. 50 lat przed Perspektywa. Wyniki badań Birkenmajera potwierdza po części Fernand Van Steenberghen: „[...] De intelligentis lub Memoriale rerum difficilium naturalium, które to dzieło Baeumker kiedyś przypisał Witelonowi, jest jednak dziełem magistra Adama z Belle-Femme (Pulchrae Mulieris). Wydaje się, że zostało ono napisane w Paryżu między 1225 a 1230. Inspiracja tego traktatu jest eklektyczna, z przewagą neoplatońską (Liber de causis, św. Augustyn, Awicenna) [...]”. Por. Filozofia w wieku XIII (Lublin: Wydawnictwo KUL 2005), 163-164. Birkenmajer zakwestionowałby z pewnością zamieszczony w ostatnim zdaniu zwrot: „z przewagą neoplatońską”.

${ }^{23}$ Questiones Meteororum zawierają wzmianki o „optyce” Witelona.

${ }^{24}$ W BJ, Przyb. 185/75 znajduje się mała karteczka, na której Birkenmajer napisał: „Może więc słowo in vacationibus na końcu traktatu De natura demonum należy rozumieć w taki sposób, że napisał jego podczas wielkiej sedeswakancji po Klemensie IV [...]” - owa „sedeswakancja” trwała od 29 XI 1248 do 1 IX 1271 roku, kiedy papieżem został Grzegorz X. 
padewskie. Im również, zdaniem Birkenmajera, zawdzięcza Witelo swoje naukowe inspiracje. Jego najbardziej znane dzieło, tj. Perspektywa, powstało po 1 stycznia 1270 roku. Witelo miał je rozpocząć już w Viterbo pod wpływem próśb Wilhelma $\mathrm{z}$ Moerbeke. Birkenmajer rozpoznał zamieszczone $\mathrm{w}$ nim fragmenty pism Awicenny, a także wypisy z głównego źródła wiedzy optycznej Witelona - Księgi perspektyw Alhazena (łac. Alhacena), przetłumaczonej jako De aspectibus lub Perpectiva $\mathrm{z}$ arabskiego na łacinę przez Gerarda $\mathrm{z}$ Cremony w XII wieku ${ }^{25}$.

Birkenmajer zwraca uwagę na to, że piśmiennictwo Witelona daje podstawy do wyrobienia sobie poglądu na istnienie poważnego ruchu umysłowego na Śląsku w tym czasie, a więc nie byłby on tam odosobniony. Należeli doń - oprócz Witelona - Ludwik z Loewenbergu, Jacobus Gosmini (doktor praw), Henryk proboszcz kościoła św. Piotra w Lignicy, oraz inny Piotr, późniejszy biskup passawski, nauczyciel księcia Włodzisława Śląskiego, późniejszego arcybiskupa salzburskiego (przebywał w Padwie w latach 1262-1265). Na początku XIV wieku czyniono nawet próby przekształcenia trywialnej (od trivium) szkoły u św. Piotra w Lignicy w wyższy zakład naukowy, niestety nieudane ${ }^{26}$.

Witelo pozostawał bez wątpienia pod wpływem filozofii Platona, niemniej jednak, jak pisze Birkenmajer, żywił także ogromne uznanie dla Arystotelesa, uważał, iż jest to „człowiek najdoskonalszy, stworzony specjalnie w tym celu, ażeby być twórcą prawdziwego poglądu na Przyrodę"27. Arystoteles nie wspomina jednak o istnieniu demonów, za to Platon wzmiankuje o nich w Fajdrosie, wskazując na istnienie czterech rodzajów jestestw, które posiadają zdolności poznawania quidditates cognoscitivae. Witelo zaś, pisząc o ich istnieniu, odwołuje się do jego autorytetu. Platon wymienia na pierwszym miejscu czyste duchy - intelligentiae separatae, a zaraz potem demony - przed ludźmi oraz zwierzętami, które wprawdzie poznają, ale nie istotę rzeczy - quidditas rerum, lecz tylko przypadłości accidentiae, dzięki zmysłom. Demony zaś są to dusze tych osób, które za złe zachowania w swoim życiu stają się po śmierci złymi duchami i po tysiącu lat tułania się z powrotem przybierają ludzkie ciała. Pozostawanie w ciele ludzkim ma tutaj znamiona kary, a ciało jest rodzajem więzienia dla duszy. Natura owych demonów jest anielsko-zwierzęca, jak zauważa Witelon, mają bowiem zarówno zdolności poznawcze, jak i ciała, ale - co należy podkreślić - według Witelona ukazują się niezwykle rzadko. Demon jest „maleficium et deforme, apparens praeter formas sensatas et notas" ${ }^{\prime 2}$. Birkenmajer przytacza także definicję Platona oraz Calcidiusa,

${ }^{25}$ Por. Anna Z. Zmorzanka, „Alhazen”, w: Powszechna encyklopedia filozofii, t. I (Lublin: Polskie Towarzystwo Tomasza z Akwinu 2000), 189.

${ }^{26}$ Birkenmajer powołuje się przy tym na „sławny dokument liginicki z r. 1309” - por. BJ, Przyb. $182 / 75$.

${ }^{27}$ Birkenmajer, „Studia nad Witelonem”, cz. 1, 14. Por. Gilson, Historia filozofii chrześcijańskiej..., 388: „[...] o ile wpływ Arystotelesa sprzyjał odrodzeniu badań w zakresie botaniki i zoologii, o tyle Platon prawie stale wspomagał rozwój geometrii i optyki".

28 Tamże, 11-12. 
który powtarza ją w swoim komentarzu do Timaiosa: „daemones esse animalia composita ex corpore et anima, sed tamen aeterna"29. Ciekawe jest u Witelona m.in. to, że podkreśla różnicę pomiędzy owymi „demonami” a „zjawami” (apparitiones), ponieważ źródłem tych ostatnich jest sam człowiek, nie mają więc one obiektywnego bytu. „Zjawy” powstają w sytuacji chorób umysłowych, miewają je więc frenetici, melancholici, epileptici oraz apoplectici. Ponadto pojawiają się w snach, a jeśli na jawie, to ich źródłem jest autosugestia bądź też złudzenia wzrokowe, które są wynikiem np. choroby oczu. Witelo był filozofem, który interesował się także medycyną i te właśnie jego zainteresowania są najbardziej widoczne w traktacie De natura daemonum, odkrytym i opisanym przez Birkenmajera.

Najciekawsze wydaje się jednak to, że Witelon konfrontuje platońskie nauczanie o „demonach”, jako źródło wiedzy o tychże, z nauczaniem Ojców Kościoła (np. św. Grzegorza) o upadku aniołów. Stwierdza, że według wiary demony to właśnie strąceni aniołowie. Zauważa przy tym, że należy wierzyć w upadek aniołów, ale że „niepodobna się nań zgodzić w świetle rozumu przyrodzonego i ze względu na porządek Wszechświata" - jak o tym pisze w swoim komentarzu Birkenmajer, dodając, że słowu daemon, tak jak je pojmuje Witelon, nie można nadawać tego znaczenia, które przypisuje się pojęciom „złego ducha” lub „szatana”. Wybitny polski mediewista zwraca przy tym uwagę na rzecz znamienną dla tamtej epoki, w której torowała sobie drogę tzw. teoria „podwójnej prawdy”, tak radykalnie zwalczana przez św. Tomasza z Akwinu. Otóż Witelo, deklarując pełne poparcie dla tego, co podaje do wierzenia wiara chrześcijańska, zaznacza, że - jeśli idzie o upadek aniołów - nie można się zgodzić na tę teorię, opierając się na rozumie. Przez to zaś, jak zauważa Birkenmajer, śląski uczony najwyraźniej skłania się ku owej teorii „podwójnej prawdy”, aczkolwiek czyni to, być może, nieświadomie.

\section{III}

Witelo był myślicielem kojarzonym słusznie z uprawianą przezeń tzw. metafizyką światła. Rozwinął ją głównie we wstępie do Perspektywy. W pismach uczonych XIII wieku „[...] metafizyka światła, noetyka światła i fizyka światła zdają się wzajemnie na siebie powoływać i potwierdzać" - zauważa Etienne Gilson ${ }^{30}$. Badania m.in. Aleksandra Birkenmajera wykazały, że Witelo nie był pod tym względem wyjątkiem na tle filozofów XIII wieku. Światło - przedmiot filozofii przyrody - stanowiło dla nich swoiste narzędzie do rozwiązywania problemów metafizycznych. Polski uczony wykazuje i podkreśla, że Witelo był właśnie przede wszystkim filozofem-przyrodnikiem. Jest to o tyle ważne, iż mediewiści zwykle postrzegali oraz oceniali filozofów w kontekście teologii uprawianej w XIII wieku (np. Martin Grabmann),

29 Tamże, 13.

${ }^{30}$ Gilson, Historia filozofii chrześcijańskiej..., 388. 
badając wpływ Metafizyki oraz pism etycznych Arystotelesa, a pomijając jego dzieła o treści przyrodniczej. Metoda Birkenmajera pozwoliła na pełniejsze niż dotąd poznanie recepcji pism fizycznych, ale także metafizycznych Arystotelesa w średniowiecznej Europie. Recepcja ta pierwotnie była pozytywna, a nawet niekiedy entuzjastyczna i był to właściwy prąd arystotelizmu. Odbiorcami tego rodzaju pism Stagiryty byli bowiem najpierw filozofowie przyrody i medycy. Dlatego w pełni uzasadnione staje się poszukiwanie analogii dla poglądów Witelona w pismach Rogera Bacona i Roberta Grosseteste. Alistair C. Crombie pisał na ten temat w swojej znanej książce o nauce średniowiecznej oraz o początkach nauki nowożytnej:

Do następców Grosseteste’a w późniejszych latach XIII w. należał Ślązak Witelo (ur. ok. 1230 r.), który opisał eksperymenty podobne do ptolemeuszowych i mające na celu określenie wielkości kątów załamania światła przechodzącego przez powietrze, wodę i szkło, przy czym kąty padania wzrastały od 10 stopni do maksimum 80 stopni. Alhazen nie mówił wprost o takich pomiarach, ale wydaje się, że Witelo zastosował tu aparat, który Alhazen opisał mając na względzie inne jego przeznaczenie ${ }^{31}$.

W teologii, którą uprawiał w Anglii Grosseteste, późniejszy biskup Lincoln, wykorzystywane były pomysły z zakresu matematyki i optyki. Pozostając pod wpływem arabskich traktatów, których tematem była optyka, Grosseteste przypisywał właśnie światłu pierwszorzędną rolę w powstaniu oraz porządku fizycznego świata.

Według Birkenmajera, historyka filozofii średniowiecznej oraz $\mathrm{w}$ równym stopniu historyka nauki, zarówno treść rozważanych wówczas zagadnień, jak i ich forma, a więc język - cała średniowieczna terminologia - wymaga specjalnych studiów mediewistycznych. Birkenmajer zwracał nadto uwagę na trudności stylu samego Witelona: „Nie da się zaprzeczyć, że styl Witelona jest ciężki i okresy są długie, zdania poboczne wadliwie często zbudowane, nierzadkie anakoluty"32. Jeszcze trudniejsza jest terminologia, np. pojęcia „forma” używa Witelo w wielu odcieniach znaczeniowych, co bardzo utrudnia przekład jego Perspektywy na język polski.

Aleksander Birkenmajer, odwołując się do właściwego tłumaczenia słów res corporeae inferiores i res corporeae superiores wykazał, że wcześniejsze, wadliwe tłumaczenia stanowiły niemniej wadliwą podstawę dla takiej interpretacji filozofii Witelona, jakoby jego zdaniem świat cielesny - analogicznie do świata ponadcielesnego, nadzmysłowego - charakteryzował się budową hierarchiczną, skąd miała wynikać określona rola światła naturalnego. Najwyżej w tej hierarchii miały być ciała niebieskie, a potem następować miał cały szereg ustopniowanych hierarchicznie bytów. Światło zaś (lumen sensibile, a więc światło dostępne zmysłom, zmysłowe) miało przenosić „wpływy” - influentie - od stopnia wyższego ku niższemu. Z pewnością tego rodzaju stopniowanie bytów nie wiąże się ze stopniem

31 Crombie, Nauka średniowieczna..., 133.

32 Birkenmajer, „Studia nad Witelonem”, cz. 2, 12. Por. BJ, Przyb. 181/75. 
ich „świetlaności” (co było typowe dla traktatu De intelligentis, fałszywie przypisywanego Witelonowi). Taka interpretacja Perspektywy, naznaczona wyraźnie wpływami neoplatońskimi, była według Birkenmajera jedynie nieuprawnioną amplifikacją. Świadczyłaby - jego zdaniem - o tym, że dzieło śląskiego myśliciela jest pod tym względem wyjątkowe jak na wiek XIII. Uważna lektura przedmowy do Perspektywy Witelona pozwoliła bowiem rozróżniać za nim jedynie dwa stopnie bytów materialnych: sfery i ciała niebieskie, tworzące obszar „gwiazd stałych”, oraz świat sublunarny, podksiężycowy. Ten podział świadczy o tym, że filozofia Witelona obejmuje integralny element syntezy scholastycznej, jakim była kosmologia Arystotelesa. Zarówno w kosmologii, jak i w średniowiecznej astronomii i astrologii używano technicznych określeń - mundus superior oraz mundus inferior - na oznaczenie obu tych światów. Witelo przyznaje światłu rolę pośrednika czy może raczej przenosiciela, medium, wpływów świata wyższego na niższy. Chodzi o światło dostrzegalne zmysłami, lumen sensibile, które „w dziwny sposób upodabnia i łączy” („mirifice assimilans et connectens”) ciała współtworzące świat wyższy z ciałami należącymi do świata niższego. Nie ma różnicy w mechanizmie wpływów (influentie) ciał niebieskich oraz naturalnych, ponieważ jedne i drugie zachodzą na podobieństwo światła. Ale tylko „na podobieństwo światła” - jak podkreśla Birkenmajer. Światło nie jest więc medium wszystkich oddziaływań i wpływów, które mają miejsce w świecie.

„Lumen sit primum omnium formarum sensibilium” (Perspektywa 129, 5) "Światło jest pierwszą formą wszystkich rzeczy zmysłowych" - zauważa Witelo, pozostając w klimacie podobnych myśli, które można łatwo odnaleźć w pismach Rogera Bacona oraz Roberta Grosseteste. Aby można było poznać i omówić sposób działania form naturalnych, a jest on głęboko ukryty, Witelo przyjął jako metodę postępowania studiowanie rzeczy widzianych, czyli wrażeń świetlnych, które przedstawiają najwyższą różnorodność, aby następnie, „per modum entium visibilium” (129, 7-8), dojść do rzeczy bardziej ukrytych, jakim jest „modus actionis formarum naturalium”. Zjawiska optyczne stały się więc przedmiotem dzieła Perspektywa i od nich wzięło ono swoją nazwę. Ten program Witelona wskazuje na ścisłą łączność fizyki oraz metafizyki, która pozostaje nabudowana na wcześniejszych badaniach. Analiza tego sposobu poszukiwania ustaleń na poziomie najgłębszym, metafizycznym, ilustruje - inaczej rzecz ujmując - ścisłą łączność pomiędzy obszarem nauk szczegółowych a filozofią jako mądrością o charakterze scalającym szczegółowe badania i obserwacje poprzez wskazywanie ich najgłębszych przyczyn, a nie oderwaną od rzeczywistości, czystą spekulacją.

Aleksander Birkenmajer zajmował się także wnikliwymi badaniami dotyczącymi miejsc i jakości kolejnych wydań Perspektywy Witelona, wymieniając je po kolei, np. wydanie z 1535 roku, następnie z Norymbergii z 1551 roku $^{33}$,

${ }^{33}$ Birkenmajer wspomina, że wydanie norymberskie (a także to z Bazylei) posiadał Jan Brożek (Broscius). Oba wydania opatrzył interesującymi uwagami. 
a wreszcie - jego zdaniem najlepsze - wydanie z roku 1572, które ukazało się w Bazylei. Dopiero te wszechstronne badania, głęboko źródłowe, dotyczące zarówno zewnętrznej strony rękopisów, jak i żmudnego wydobywania ich prawdziwych, a nie tylko domniemanych treści, co jest możliwe nieraz po latach studiów, prowadzą ku ustaleniom trudnym do zakwestionowania i jak najdalszym od krzywdzących i nieprawdziwych schematów dotyczących tej epoki, w której między innymi działał naukowo oraz wysnuwał filozoficzne wnioski śląski uczony Witeliusz.

\section{Podsumowanie}

Badania mediewistyczne wymagają wszechstronnego przygotowania, zarówno historycznego, jak i filologicznego oraz filozoficznego. Bardzo ważna jest przy tym także znajomość podstaw nauk ścisłych. Wyraźnie widać to na przykładzie badań oraz osiągnięć polskiego mediewisty, o których była mowa powyżej, mimo że dotyczą one jedynie wybranego trzynastowiecznego uczonego. To badanie wybranych tekstów wydaje się tutaj właściwym wprowadzeniem w epokę, która może być wręcz wzorem myślenia filozoficznego. Ale ktoś mógłby współcześnie powiedzieć, że stare teksty, jako przedmiot badań pasjonatów, nie inicjują w istocie otwartej, filozoficznej postawy, która wymaga przede wszystkim otwartości na percepcję świata, a także znajomości języka, w którym można filozofować. Jak więc prawidłowo rozumieć „źródłowość języka”? Czy źródłem jest rzeczywiście to, co przedfilozoficzne, a zarazem spontaniczne oraz naturalne albo wręcz przyrodnicze? Z pewnością tak, jeśli człowieka zaliczymy do wielkiej rodziny wszystkich istot żywych (wyjąwszy duchy czyste oraz demony), które aby przetrwać, muszą np. polować oraz tworzyć większe, zorganizowane grupy. Człowiek na poziomie przyrody współtworzy świat wszystkich innych $\zeta \omega$ a i o tym dobrze wiedzieli już starożytni Grecy. Jeśli jednak język służy głównie biologicznemu przetrwaniu, a przetrwanie to dotyczy jednostek lub też całych ludzkich (i zwierzęcych) „stad” czy „watah”, to filozofia jest wyłącznie żałosnym pięknoduchostwem osób, które na skutek nadmiaru wolnego czasu skłaniają się ku tego rodzaju aktywności. Jedno jest przy tym pewne - że powyższy zarzut towarzyszy jej od początku, a już na pewno od czasów Sokratesa. Ten wychowawca młodzieży, odwołując się do naturalnej u młodego człowieka skłonności do poznawania świata, nie tylko pozwalał na stawianie najtrudniejszych nawet pytań, lecz także pomagał w „rodzeniu się” myśli, przytaczając jednak często poglądy zasłyszane gdzie indziej, u innych myślicieli. Samodzielne sądy wymagają bowiem konfrontacji z poglądami innych, zakładając wstępnie wysiłek zrozumienia ich. Wypracowane w starożytnej Grecji, przejęte następnie przez Rzym dobra kultury umysłowej stały się żywym źródłem dla tworzącej się Europy. 
Źródłowość języka polskiego obejmuje także jego historię, a więc wpływy języków obcych, ale przede wszystkim łaciny. Jesteśmy wszak w kręgu kultury europejskiej. Spór o łacinę w szkolnictwie jako mniej lub bardziej istotne oraz żywe źródło polskiej kultury piśmienniczej i umysłowej jest bardzo dawny i na pewno sięga wieku XVIII. Czy należy definitywnie z nią zerwać w procesie kształcenia młodego pokolenia? Takie pomysły istniały już w wieku „oświecenia”. Pisze o tym Zenon Klemensiewicz, zamieszczając przy tej okazji interesujące wypowiedzi ówczesnych luminarzy:

Spór o łacinę trwał. Trudno było zaprzeczyć jej wypróbowanej przydatności w nauce i nauczaniu. Krasicki podkreślał, że „wychowanie młodzieży naszej nierównie teraz jest cięższe, niż przedtem było, a temu winne rozmaite języki, których się uczyć muszą. Źle zrobili ci, którzy, zarzuciwszy łacinę, wszystko rodowitym językiem pisać chcieli [...] Gdyby za wspólną narodów zgodą jeden był język wybrany do nauk, wzniosłyby się w dwójnasób. Do żadnego się w szczególności nie przywiązuję, aleby się godziło przywrócić łaciński do dawnej posesyi” [Pan Podstoli na trzy ksiegi podzielony, Warszawa 1778, cz. I., ks. I, s. 47 i 49]. J. Rogaliński ganił tych, którzy lekceważyli łacinę, jako język martwy. A nie chcą wiedzieć, „że jest kluczem umiejętności. Inne są strumieniami, a on źródłem, w którym naturalniejsza zawsze czerpać zwykła się żywość” [„Monitor”, nr 26, 26 III 1766] $]^{34}$.

Ponieważ jej znajomość jest współcześnie nikła, można tylko projektować jej nauczanie w nowych programach szkolnych, dążąc - o ile to możliwe - aby się tam pojawiła, choćby na podstawowym poziomie. Okazało się bowiem, że totalny brak znajomości tego języka naruszył podstawy tożsamości kulturowej nie tylko Polaków, lecz także wszystkich innych Europejczyków. Średniowiecze zaś jest tą epoką, do dzisiaj bardzo źle traktowaną w programach nauczania, do której warto powracać nie tylko w poszukiwaniu mocnych fundamentów kulturowej tożsamości Europejczyka, związanych z powszechną znajomością łaciny pośród osób wykształconych. Również dlatego, że epoka ta dostarczyła przykładów współpracy intelektualnej pośród osób należących z pewnością do różnych kultur. To filozofia tworzyła i tworzy - a także, być może, utworzy, mimo wszelkich trudności - właściwą płaszczyznę spotkania różnych kultur. Warto więc na zakończenie przypomnieć i tutaj to, co w lapidarnym skrócie ujął wybitny współczesny polski mediewista:

Mimo, że islamscy, żydowscy i chrześcijańscy myśliciele różnili się zdecydowanie przekonaniami religijnymi, które traktowano niezwykle poważnie i jednoznacznie, nie podejmując żadnych prób synkretycznego ich łączenia, to jednak wypracowali razem spójne i cenne dziedzictwo intelektualne, które stało się punktem wyjścia

${ }_{34}$ Zenon Klemensiewicz, Historia języka polskiego, t. III (Warszawa: Państwowe Wydawnictwo Naukowe 1985), 576. 
zarówno dla nowożytnej myśli filozoficznej, jak również nowożytnego, ujmującego matematycznie rzeczywistość, przyrodoznawstwa ${ }^{35}$.

Właściwą płaszczyznę porozumienia między różnymi kulturami może więc i dzisiaj tworzyć filozofia, a jej znajomość, dotycząca tak ważnej dla Europy epoki Średniowiecza, powinna być dzisiaj znacząco pogłębiona. Dotyczy to w sposób oczywisty także przynajmniej podstaw znajomości języka łacińskiego. Tylko bowiem w ten sposób można realnie projektować wychowanie człowieka integralnego, w którym naturalna pasja poznawcza będzie podtrzymywana zarówno żywym, dialogicznym kontaktem z nauczycielem i współuczniami, jak i osiągnięciami uczonych minionych epok, którzy pozostawili po sobie dzieła warte i dzisiaj studiowania.

Streszczenie: Zarówno warsztat naukowy Birkenmajera, jak i metoda jego pracy, a także jej osiągnięcia mogą stać się przykładem właściwego podejścia naukowego do Średniowiecza. Obraz tej epoki, jaki się przy tym rysuje, jest radykalnie odmienny od królujących na ten temat stereotypów, obecnych ciągle jeszcze w programach szkolnych.

Aleksander Birkenmajer (1890-1967) był znakomitym polskim mediewistą, dzięki wszechstronnemu wykształceniu doskonale przygotowanym do pracy nad średniowiecznymi rękopisami. W swoich pracach wielokrotnie podkreślał konieczność dostrzegania ścisłego związku pomiędzy historią filozofii oraz historią nauk matematyczno-przyrodniczych. Dyrektywą metodologiczną stało się dla niego to, że średniowieczna filozofia o wiele bardziej niż myśl późniejsza powiązana była z całą ówczesną wiedzą, aczkolwiek jej zakres był nieporównanie mniejszy niż dzisiejszych nauk szczegółowych. W swoich badaniach nad filozofią Witelona Birkenmajer podkreślał, że był on filozofem - przyrodnikiem, który posługiwał się światłem w rozwiązywaniu metafizycznych problemów - co czyniło wówczas wielu, np. Ryszard Bacon czy też Robert Grosseteste. Perspektywa Witelona jest w istocie traktatem matematyczno-fizycznym ze wstępem o charakterze metafizycznym.

Birkenmajerowi udało się m.in. ustalić, że Witelon jest autorem traktatu De natura daemonum, którego znajomość może wpłynąć istotnie na rozumienie całości jego filozoficznych poglądów. Polski mediewista zauważył nadto, że w traktacie znajdują się symptomy tzw. teorii podwójnej prawdy, pod której wpływem bywał śląski uczony - być może nie do końca świadomie. Birkenmajer wydobył i przekonująco opisał pewne wątki filozofii Witelona, które znacząco ograniczają interpretowanie jego myśli w paradygmacie neoplatońskim.

Słowa kluczowe: metoda naukowa mediewisty, związek filozofii z nauką w epoce Średniowiecza, Witelo jako uczony i filozof

${ }^{35}$ Bp Stanisław Wielgus, Z obszarów średniowiecznej myśli islamskiej, żydowskiej i chrześcijańskiej (Płock: Płocki Instytut Wydawniczy 2002), 5. 


\section{Bibliografia}

Birkenmajer, Aleksander. Biblioteka Jagiellońska, Przybytki: 181/75; 182/75; 184/75; 185/75.

Birkenmajer, Aleksander. „Studia nad Witelonem”, cz. 1. „Dwa nieznane pisemka Witelona”. W: BJ, Przyb. 180/75. Kraków: Nakładem Polskiej Akademii Umiejętności, 1921.

Crombie, Alistair Cameron. Nauka średniowieczna i początki nauki nowożytnej, t. I. Warszawa: Instytut Wydawniczy PAX, 1960.

Gilson, Etienne. Historia filozofii chrześcijańskiej w wiekach średnich. Warszawa: Instytut Wydawniczy PAX, 1987.

Kijewska, Agnieszka. „Wprowadzenie”. W: Przewodnik po filozofii średniowiecznej. Od św. Augustyna do Joachima z Fiore, red. Agnieszka Kijewska. Kraków: Wydawnictwo WAM, 2012.

Klemensiewicz, Zenon. Historia języka polskiego, t. III. Warszawa: Państwowe Wydawnictwo Naukowe, 1985.

Kuksewicz, Zdzisław. Zarys filozofii średniowiecznej. Warszawa: Państwowe Wydawnictwo Naukowe, 1973.

Kurdziałek, Marian. „Aleksander Birkenmajer. «Historyk filozofii średniowiecznej»”. W: Średniowiecze w poszukiwaniu równowagi między arystotelizmem a platonizmem. Studia i artykuły. Lublin: TN KUL, 1996, 7-16.

Kurdziałek, Marian. „Udział ks. Konstantego Michalskiego i Aleksandra Birkenmajera w odkrywaniu filozofii średniowiecznej”. W: Średniowiecze w poszukiwaniu równowagi między arystotelizmem a platonizmem. Studia i artykuły. Lublin: TN KUL, 1996, 17-33.

Nowak, Lucyna. „Rękopiśmienne świadectwa recepcji pism Dunsa Szkota na Uniwersytecie Krakowskim. Katalog dzieł". W: Błogosławiony Jan Duns Szkot. 1308-2008. Materiały Międzynarodowego Sympozjum Jubileuszowego z okazji 700-lecia śmierci bł. Jana Dunsa Szkota, Katolicki Uniwersytet Lubelski Jana Pawła II, 8-10 kwietnia 2008, red. Edward I. Zieliński OFMConv, Roman Majeran. Lublin: Wydawnictwo KUL, 2010, 743-761.

Polski słownik biograficzny, t. II. Kraków: Nakładem Polskiej Akademii Umiejętności, 1936.

Przymusiała, A. „Ks. Konstanty Michalski (1879-1947)”. Studia Philosophiae Christianae 1 (1966), t. 2/1, 265-273.

Sajdek, Wiesława. „Od redakcji”. W: Czasy katedr - czasy uniwersytetów. Źródła jedności narodów Europy, red. Wiesława Sajdek. Lublin: Wydawnictwo KUL, 2005, 5-6.

Sajdek, Wiesława. „Recepcja historii filozofii średniowiecznej wśród studentów”. Społeczeństwo i Rodzina. Stalowowolskie Studia KUL 1 (2004), 13-22.

Steenberghen, Fernand Van. Filozofia w wieku XIII. Lublin: Wydawnictwo KUL, 2005.

Wielgus, Stanisław, bp. Z obszarów średniowiecznej myśli islamskiej, żydowskiej i chrześcijańskiej. Płock: Płocki Instytut Wydawniczy, 2002.

Woźniczka, Maciej, Perek, Marek. „Wstęp. Relacja kanon - apokryf”. W: Apokryficzność (w) filozofii. Nielanty/pozaortodoksyjne dyskursy filozoficzne, red. Maciej Woźniczka, Marek Perek. Częstochowa: Wydawnictwo im. S. Podobińskiego, 2017, 7-28.

Zmorzanka, Anna Z. „Alhazen”. W: Powszechna encyklopedia filozofii, t. I. Lublin: Polskie Towarzystwo Tomasza z Akwinu, 2000. 